RESIDENT

\& FELLOW

SECTION

Section Editor

Mitchell S.V. Elkind,

MD, MS

S. Auvin, $\mathrm{MD}, \mathrm{PhD}$

E. Lejay, MD

C. Delanoe, MD

I. Denjoy, MD

J.-M. Lupoglazoff, MD, $\mathrm{PhD}$

J.-C. Mercier, MD, PhD

L. Titomanlio, MD, $\mathrm{PhD}$

Address correspondence and reprint requests to Dr. Luigi Titomanlio, Pediatric Emergency Department, Robert Debré University Hospital, 48, Bld Sérurier, 75019 Paris, France luigi.titomanlio@rdb.aphp.fr

\title{
Clinical Reasoning: Seizures in a child with sensorineural deafness and agitation
}

\section{SECTION 1}

A 4-year-old girl was seen in the pediatric emergency department because of a first generalized tonic-clonic seizure that occurred at school. The seizure was preceded by a sudden, prolonged attack of unconsciousness, lasted 5 minutes, and was followed by drowsiness.

The parents were first cousins of Algerian descent. She had an unremarkable family history. Pregnancy and delivery were uneventful. At age 4, she under- went bilateral cochlear implantation for congenital sensorineural deafness.

Neurologic examination was notable for deafness and marked agitation, which was reported to be usual by her parents. Psychomotor development was mildly delayed.

\section{Questions for consideration:}

1. What is your evaluation of this first nonfebrile seizure?

2. Would you prescribe a treatment and, if so, which one? 


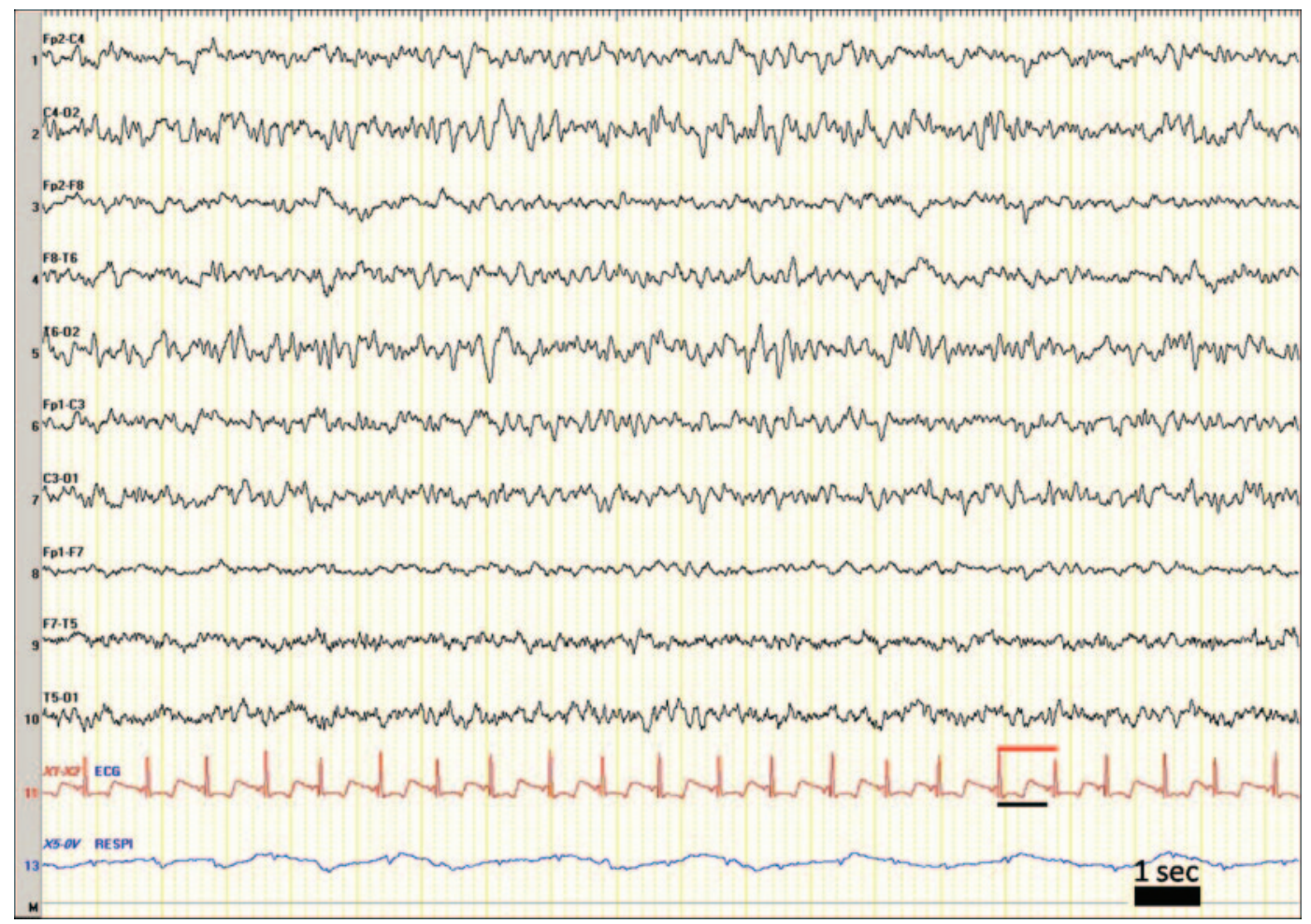

EEG was performed 1 day after the seizure (see Section 3 for its interpretation).

\section{SECTION 2}

When a child is evaluated for a probable first seizure, it is important to assess if it was really a seizure and if it was really a first attack. There is currently no test that proves that a seizure occurred. About half of the children with a presumed first seizure have had a prior unrecognized seizure. ${ }^{1}$ In our patient, it was the first episode.

After it is established that a first seizure occurred, it is important to evaluate if it was a provoked seizure. Population-based studies indicate that $25 \%-$ $30 \%$ of first seizures are "acute symptomatic," indicating that they are caused by a brain insult or a metabolic or toxic disturbance of brain function. ${ }^{2}$
Among these, syncope that induces seizure is particularly challenging to diagnose. When clinical examination is normal, routine laboratory testing is unlikely to be revealing in a child with a first nonfebrile seizure. ${ }^{3}$

Rectal diazepam was prescribed in case of prolonged seizure, ${ }^{4}$ and oral hydroxyzine was started for psychomotor agitation.

EEG recording was done 1 day after the initial seizure (figure).

\section{Questions for consideration:}

1. What is your conclusion about diagnosis from the EEG?

2. Would you obtain additional tests? 


\section{SECTION 3}

A few slow spikes were noted in the posterior area of the EEG, and were considered within the normal range for her age. The electrocardiogram (ECG) channel of the EEG recording was suggestive of a cardiac conduction defect (short PR, long QT). On the figure, the black bar represents the measure of the QT space. The red bar represents the RR space permitting the evaluation of the corrected QT $\left(\mathrm{QT}_{\mathrm{c}}=\mathrm{QT} / \sqrt{ } \mathrm{RR}\right)$. In her case, the $\mathrm{QT}_{\mathrm{C}}$ was $>0.7$ seconds.

A standard ECG was then performed. A long QT was confirmed (QTc measured at 0.6 second, normal value $<0.44$ second), suggesting a long QT syndrome (LQTS). Hydroxyzine was immediately stopped, being contraindicated in LQTS, and betablocker therapy was started.

The sudden syncopal episode preceding her first seizure was therefore considered of cardiac origin, and the generalized tonic-clonic movements were considered to be secondary to transient cerebral hypoxia. Congenital deafness associated with long QT is suggestive of Jervell and Lang-Nielsen syndrome (JLNS or LQT1), and this was confirmed by the identification of a homozygous mutation of the voltage-gated potassium channel gene KCNQ1.

At follow-up at age 5 years, she looked healthy and calm. She had not experienced any further syncopal episodes. Neurologic examination was normal, except for bilateral deafness. Psychomotor development was within normal range. Her QTc was 0.53 second. Awake and sleep EEG was normal.

DISCUSSION The patient presented with cardiovascular syncope, with abnormal tonic-clonic movements due to cerebral hypoxia. This etiology could have been considered at the emergency department because of sudden, prolonged unconsciousness preceding the seizure.

Misdiagnosis of epilepsy is common, ${ }^{5}$ especially in children. Clinically, arrhythmic episodes may be difficult to differentiate from epilepsy on clinical grounds. Seizure-related cardiac arrhythmias (i.e., bradycardia or asystole) have been reported, ${ }^{6}$ as well as sudden falls during focal seizures. ${ }^{7}$ Clinical features and EEG recording permit exclusion of the Panayiotopoulos syndrome that may mimic cardiac syncope. ${ }^{8}$ This is a benign, common childhood epilepsy with autonomic seizures imitating syncope, migraine, or gastroenteritis. Its autonomic manifestations may include cardiorespiratory alterations.

A delayed diagnosis of LQTS is unfortunately frequent. Long QT symptoms are often attributed to alternative diagnoses, most commonly epilepsy. ${ }^{9}$ In this child, JLNS was diagnosed. It is caused by homozygous mutations of the voltage-gated potassium channel gene KCNQ1 and is characterized by deafness and a prolongation of the QT interval at baseline ECG with a high risk of life-threatening arrhythmias or sudden cardiac death. ${ }^{10}$

Investigators recently showed that a direct link may exist between LQTS and epilepsy. ${ }^{11}$ They found that patients with LQT2 (KCNH2 mutations) had more frequent epilepsy than patients clinically evaluated and genetically tested for LQTS, suggesting that perturbations in the $\mathrm{KCNH}$-encoded potassium channel may confer susceptibility for recurrent seizure activity.

Given the potentially preventable mortality of LQTS, physicians investigating syncope and seizures should maintain a high index of suspicion for long QT syndrome as an etiology.

The use of EEG and ECG recordings is often necessary to make the diagnosis. When personal or family history of syncope, deafness, or abnormal ECG is present, the use of drugs that may be responsible for a prolongation of QTc should be avoided until the investigations permit exclusion of a long QT.

\section{DISCLOSURE}

Dr. Auvin, Dr. Lejay, Dr. Delanoe, Dr. Denjoy, Dr. Lupoglazoff, and Dr. Mercier report no disclosures. Dr. Titomanlio serves as an Associate Editor of Prospettive in Pediatria.

\section{REFERENCES}

1. Hamiwka LD, Singh N, Niosi J, Wirrell EC. Diagnostic inaccuracy in children referred with "first seizure": role for a first seizure clinic. Epilepsia 2007;48:1062-1066.

2. Hirtz D, Berg A, Bettis D, et al. Practice parameter: treatment of the child with a first unprovoked seizure: report of the Quality Standards Subcommittee of the American Academy of Neurology and the Practice Committee of the Child Neurology Society. Neurology 2003;60:166-175.

3. Valencia I, Sklar E, Blanco F, et al. The role of routine serum laboratory tests in children presenting to the emergency department with unprovoked seizures. Clin Pediatr 2003;42:511-517.

4. Kriel RL, Cloyd JC, Pellock JM, Mitchell WG, Cereghino JJ, Rosman NP. Rectal diazepam gel for treatment of acute repetitive seizures: The North American Diastat Study Group. Pediatr Neurol 1999;20:282-288.

5. Uldall P, Alving J, Hansen LK, Kibaek M, Buchholt J. The misdiagnosis of epilepsy in children admitted to a tertiary epilepsy centre with paroxysmal events. Arch Dis Child 2006;91:219-221.

6. Rubboli G, Bisulli F, Michelucci R, et al. Sudden falls due to seizure-induced cardiac asystole in drug-resistant focal epilepsy. Neurology 2008;70:1933-1935.

7. Leung H, Schindler K, Kwan P, Elger C. Asystole induced by electrical stimulation of the left cingulate gyrus. Epileptic Disord 2007;9:77-81. 
8. Covanis A. Panayiotopoulos syndrome: a benign childhood autonomic epilepsy frequently imitating encephalitis, syncope, migraine, sleep disorder, or gastroenteritis. Pediatrics 2006;118:e1237-e1243.

9. MacCormick JM, McAlister H, Crawford J, et al. Misdiagnosis of long QT syndrome as epilepsy at first presentation. Ann Emerg Med 2009;54:26-32.
10. Crotti L, Celano G, Dagradi F, Schwartz PJ. Congenital long QT syndrome. Orphanet J Rare Dis 2008; $3: 18$.

11. Johnson JN, Hofman N, Haglund CM, Cascino GD, Wilde AA, Ackerman MJ. Identification of a possible pathogenic link between congenital long QT syndrome and epilepsy. Neurology 2009;72:224-231. 


\title{
Neurology
}

\section{Clinical Reasoning: Seizures in a child with sensorineural deafness and agitation}

\author{
S. Auvin, E. Lejay, C. Delanoe, et al.
}

Neurology 2010;74;e61-e64

DOI 10.1212/WNL.0b013e3181d8c1e4

\section{This information is current as of April 12, 2010}

Updated Information \&

Services

References

Subspecialty Collections

Permissions \& Licensing

Reprints including high resolution figures, can be found at:

http://n.neurology.org/content/74/15/e61.full

This article cites 11 articles, 4 of which you can access for free at: http://n.neurology.org/content/74/15/e61.full\#ref-list-1

This article, along with others on similar topics, appears in the following collection(s):

All Epilepsy/Seizures

http://n.neurology.org/cgi/collection/all_epilepsy_seizures

All Pediatric

http://n.neurology.org/cgi/collection/all_pediatric

Clinical neurology history

http://n.neurology.org/cgi/collection/clinical_neurology_history

Generalized seizures

http://n.neurology.org/cgi/collection/generalized_seizures

Syncope

http://n.neurology.org/cgi/collection/syncope

Information about reproducing this article in parts (figures,tables) or in its entirety can be found online at:

http://www.neurology.org/about/about_the_journal\#permissions

Information about ordering reprints can be found online:

http://n.neurology.org/subscribers/advertise

Neurology ${ }^{\circledR}$ is the official journal of the American Academy of Neurology. Published continuously since 1951, it is now a weekly with 48 issues per year. Copyright . All rights reserved. Print ISSN: 0028-3878. Online ISSN: 1526-632X.

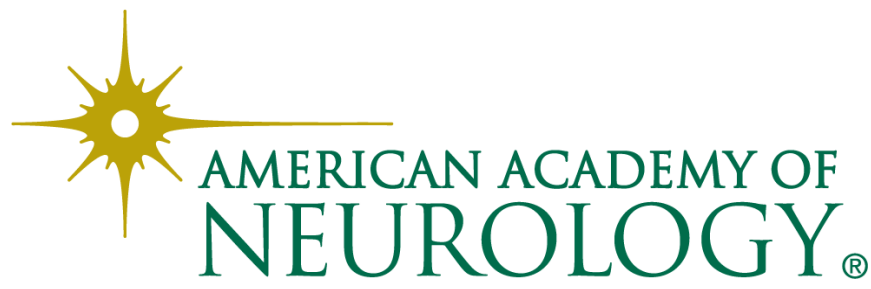

